This article focuses on the opposition to the New Zealand Government's Roads of National Significance programme to examine the individualistic and collective forms of political engagement that underpin contestation of expressway proposals and the challenges involved in forming an anti-expressway campaign that transcends locally based opposition. Utilising Ernesto Laclau's notion of populism, it is argued that, in a post-political planning context, a reliance on an individualistic or institutionalist political strategy can restrain collective action and the development of effective supra-local or national campaigns. The populist and institutionalist logics underpinning the campaigns against the Kāpiti expressway proposal reveal the shared interests between activists and local opposition groups and the potential for progressive forms of populist action on environmental issues and transport policy. 


\section{The Populist and Institutionalist Logics of Anti-Expressway Campaigns in Aotearoa New Zealand}

\section{MORGAN HAMLIN}

In 2009, a national road-building programme called the Roads of National Significance (RoNS) was announced by the National-led government. The programme involved several controversial expressway proposals, including the contentious Kāpiti expressway (MacKays to Peka Peka section) in the Wellington region, the focus of this article. Local campaigns to stop the Kāpiti expressway and other expressway proposals from proceeding emerged, but supra-local or nationwide antiexpressway campaigns against the national RoNS programme did not materialise. This is interesting in the sense that, often, effective opposition campaigns can only be achieved by connecting a local struggle to wider trans-local, supra-local, or national issues and gaining support from non-local actors. ${ }^{1}$ As infrastructure projects are often proposed by powerful or well-resourced non-local actors and organisations, effective opposition can depend on a supra-local or national response. ${ }^{2}$ Moreover, the RoNS is a national programme and expanding carbon-based transport and the system of automobility with new expressways can be readily critiqued on broader

1 Christopher Rootes, 'From Local Conflict to National Issue: When and How Environmental Campaigns Succeed in Transcending the Local,' Environmental Politics 22, no. 1 (2013): 95-114.

2 Rootes, 'From Local Conflict'. 
environmental grounds, such as climate change. ${ }^{3}$

It is common for locally based groups to oppose particular infrastructure proposals such as highways, airport extensions, and facilities for energy and waste without forming supra-local campaigns or connecting local opposition to a national issue. International studies on this phenomenon from English-speaking countries have concluded that it is rare for a local campaign to expand to a sustained supra-local or national campaign that opposes multiple infrastructure plans or a government's infrastructure programme. The public-policy context, alliances and possibilities for geographic expansion, the determination of campaigners, community characteristics and political-opportunities structures, and the availability and use of meaningful discourses can all limit or increase the likelihood that local objections will expand to a supra-local or national campaign. ${ }^{4}$

To understand the challenges involved in forming supra-local or national anti-expressway campaigns, I investigate the individualistic and collective modes of political engagement that are mobilised by opponents. This article has been developed from my broader research on public involvement in the proposed Kāpiti expressway. ${ }^{5}$ I develop new insights in this article by arguing that individualistic or institutionalist forms of

3 Crystal Legacy, 'Transforming Transport Planning in the Postpolitical Era,' Urban Studies 53, no. 14 (2016): 3108-3124; David Banister, 'Cities, Mobility and Climate Change,' Journal of Transport Geography 19, no. 6 (2011): 1538-1546.

4 Rootes, 'From Local Conflict'; Steven Griggs and David Howarth, 'Populism, Localism and Environmental Politics: The Logic and Rhetoric of the Stop Stansted Expansion Campaign,' Planning Theory 7, no. 2 (2008): 123-144; Hilary Schafer Boudet, 'From NIMBY to NIABY: Regional Mobilization Against Liquefied Natural Gas in the United States,' Environmental Politics 20, no. 6 (2011): 786-806; Brian Doherty, 'Paving the Way: The Rise of Direct Action Against Road-Building and the Changing Character of British Environmentalism,' Political Studies 47, no. 2 (1999): 275-291; Edward Walsh, Rex Warland, and Douglas Clayton Smith, Don't Burn it Here: Grassroots Challenges to Trash Incinerators (Pennsylvania: Penn State University Press, 1997); Peter North, "'Save our Solsbury!": The Anatomy of an Anti-Roads Protest,' Environmental Politics 7, no. 3 (1998): 1-25.

5 Morgan Hamlin, 'The Käpiti Distressway': A Sociological Case Study of Public Involvement in a Socio-Technical Controversy (PhD thesis, Victoria University of Wellington, 2016); 'Antagonism, Technology, and Public Involvement in the Kāpiti Expressway Project,' New Zealand Sociology 31, no. 5 (2016): 110-130. 
political engagement in this country can impede the creation of supra-local or national anti-expressway campaigns by channelling political energy into fault-finding exercises that are focused on the technical details of a particular proposal. Infrastructure proposals are often developed within a planning process that encourages individualistic forms of political engagement. Such forms of engagement are often seen as a form of 'post-political' planning that seeks to find technocratic or rationalistic solutions and limits opportunities for the public to fundamentally challenge decisions from within the formal planning process by focusing debate on 'narrow consultation briefs'. ${ }^{6}$ When political spaces for fundamental disagreement are suppressed, new, informal political spaces outside of the formal planning process may be created by citizens; this phenomenon has been called a 'post-political condition'. ${ }^{8}$ Although informal political spaces and collective action can emerge in response to post-political planning efforts, the scale of political action often remains local or is reactionary. ${ }^{9}$

Due to the expert and inaccessible style of institutionalist political engagement, it is important to understand how citizens effectively engage with public issues through existing institutional arrangements and collective forms of action. In an increasingly diverse society, where public issues are embedded in complex legal and political processes, how can citizens launch effective opposition by joining forces to connect local objections to supra-local or national issues? Here, I investigate how local anti-expressway groups and a national environmental organisation drew on institutionalist and populist political logics to oppose the Kāpiti expressway proposal and the wider RoNS programme.

6 Ralph Tafon, David Howarth, and Steven Griggs, 'The Politics of Estonia's Offshore Wind Energy Programme: Discourse, Power and Marine Spatial Planning,' Environment and Planning C 37, no. 1 (2019): 157-176; Legacy, 'Transforming Transport Planning,' 3110.

7 Graham Haughton and Phil McManus, 'Participation in Postpolitical Times: Protesting WestConnex in Sydney, Australia,' Journal of the American Planning Association 85, no. 3 (2019): 321-334.

8 Legacy, 'Transforming Transport Planning,' 3109.

9 Legacy, 'Transforming Transport Planning.' 
Populism, especially right-wing populism, as a movement, organisation, or ideology, ${ }^{10}$ is a controversial term. Populism is often viewed negatively, as it is associated with forms of politics that are based on exclusion, fear, opportunism, racism, and xenophobia, to name just a few of the issues. ${ }^{11}$ However, there is also growing interest in populism as a theoretical concept and as a form of progressive politics mobilised by activists and groups who campaign against controversial government policies, decisions, and, in particular, public-infrastructure proposals. ${ }^{12}$ As Moffit and Tormey discuss, populism can be understood as an ideology, a discourse and logic, a strategy, and a 'political style'. ${ }^{13}$ Here, following other scholars interested in understanding progressive forms of collective resistance to infrastructure proposals, I focus on populism as a political logic. ${ }^{14}$

Analysing the institutionalist and populist political logics that underpin anti-expressway campaigns is relevant for understanding progressive forms of collective action against post-political planning processes that limit the scope for public disagreement. Institutionalist forms of engagement can be appropriate for certain groups and for certain situations, especially if they are well-resourced. ${ }^{15}$ However, this mode of engagement should be seen in the wider post-political planning context that seeks to limit effective opposition and use public consultation techniques to depoliticise controversial

10 Steven Griggs and David Howarth, 'Protest Movements, Environmental Activism and Environmentalism in the United Kingdom,' in The SAGE Handbook of Environment and Society, eds. Jules Pretty et al (London: Sage, 2007), 314-324; Cas Mudde and Cristóbal Rovira Kaltwasser, Populism: A Very Short Introduction (Oxford: Oxford University Press, 2017).

11 Julie MacArthur and Steve Matthewman, 'Populist Resistance and Alternative Transitions: Indigenous Ownership of Energy Infrastructure in Aotearoa New Zealand,' Energy Research \& Social Science 43 (2018): 16-24; Ruth Wodak, The Politics of Fear: What Right-Wing Populism Discourses Mean (London: Sage, 2015).

12 Griggs and Howarth, 'Protest Movements'; MacArthur and Matthewman, 'Populist Resistance.'

13 Benjamin Moffit and Simon Tormey, 'Rethinking Populism: Politics, Mediatisation and Political Style,' Political Studies 62, no. 2 (2014): 381-397.

14 Griggs and Howarth, 'Populism'; MacArthur and Matthewman, 'Populist Resistance.'

15 Legacy, 'Transforming Transport Planning'; Rootes, 'From Local Conflict.' 
transport proposals, among others, as 'reasonable'. ${ }^{16}$ Progressive populism and other forms of collective engagement outside of the formal planning process can be understood as attempts by actors to effectively counter the depoliticising, post-political 'syndrome' and raise larger questions about transport and urban development that have been 'foreclosed from public view. ${ }^{17}$ In this post-political context, collective forms of action can repoliticise transport and other proposals framed as 'reasonable' as important public issues that can have negative impacts on communities, human health, and the environment. ${ }^{18}$ Politicising contentious transport proposals can help raise public awareness of roads as wider public and environmental issues and not just local problems. By remaining local, campaigns against locally unwanted infrastructure and facilities run the risk of being labelled as a form of NIMBYism. ${ }^{19}$

To find out how a single-issue campaign can broaden its scope, I briefly compare the lack of supra-local and national anti-expressway campaigns in Aotearoa New Zealand to the road protests in the UK, US, and Australia. I then outline my theoretical approach and research methods. I utilise Laclau's, and Griggs and Howarth's, concepts of populism and institutionalism to examine the protests organised by local opposition groups and the environmental organisation Generation Zero. ${ }^{20}$ Finally, I discuss the challenges of forming national anti-expressway campaigns in Aotearoa New Zealand.

16 Haughton and McManus, 'Participation,' 321.

17 Tafon et al., 'The Politics,' 174; Crystal Legacy et al., 'Planning the Post-

Political City: Exploring Public Participation in the Contemporary Australian City,'

Geographical Research 56, no. 2 (2018): 179.

18 Haughton and McManus, 'Participation,' 321.

19 Rootes, 'From Local Conflict.'

20 Ernesto Laclau, On Populist Reason (London: Verso, 2005); Griggs and Howarth, 'Populism.' 


\section{Roads of local, supra-local, and national significance}

In Aotearoa New Zealand, sustained supra-local and national anti-roads campaigns have not materialised. The country's small population, which is spread over a relatively large area, has meant that many large road projects have avoided dense urban areas and have been able to dodge significant public opposition. While large highway projects have been publicised in national news media, they have not resulted in sustained supra-local or national mobilisations. ${ }^{21}$ For example, Auckland's eastern motorway and Wellington's inner-city bypass are notable projects that received national news coverage and sustained local opposition. Historically, the lack of supra-local or national anti-roads campaigns is not surprising considering Aotearoa New Zealand's small population, automobile dependence, and low public-transportation patronage. ${ }^{22}$

When the National-led government announced that it was planning to build seven RoNS, the proposals faced fierce local opposition from a diverse range of individuals, groups, and organisations. All seven road projects have received extensive media coverage on the benefits and problems of building large motorways in urban environments. In particular, the Kāpiti expressway, which is one section within the larger Wellington Northern Corridor RoNS proposal, generated significant controversy. The proposal was controversial for many reasons, but, generally, residents were concerned that a large, four-lane expressway would bisect the communities along the Kāpiti coast and create various problems regarding noise, pollution, and the environment. Some residents believed that the expressway proposal would not be needed if the current highway was upgraded and a smaller, two-lane local road (known as the Western-link Road) was built on the proposed expressway route to help ease highway congestion. From 2009 to 2013, approximately seven public meetings and nine protests were reported on in the media. Additionally, the New Zealand Transport Agency (NZTA)

21 Paul Mees and Jago Dodson, 'Backtracking Auckland? Technical and Communicative Reason in Metropolitan Transport Planning,' International Planning Studies 12, no. 1 (2007): 35-53.

22 Mees and Dodson, 'Backtracking Auckland,' 37. 
received over 1,600 submissions during the public consultation period, and the Board of Inquiry received over 700 submissions. This proposal also received national news coverage when the climate-change organisation Generation Zero used it as an example of why Aotearoa New Zealand needs to end its dependence of fossil fuels in order to combat climate change. However, while the Kāpiti expressway became part of Generation Zero's wider environmental campaign, there have been no sustained supra-local or national campaigns against the RoNS programme.

A brief examination of the supra-local and national road protests in other English-speaking countries suggests that this need not be the case. Expressway protesters in the UK and US have launched national campaigns which relied on collective forms of politics and drew support from a range of social and environmental movements. ${ }^{23}$ For example, social-movement groups played an important role in opposing the Interstate Highway System in the US in the 1950s and 1960s. ${ }^{24}$ In the UK, environmental groups played an important role in the direct-action protests against the Conservative government's Roads for Prosperity in the 1990s. As Sheller and Urry note, 'by 1994, in the UK, the scale of grass-roots protest against the construction of new roads had risen to such a level that it was described as "the most vigorous new force in British environmentalism"'. ${ }^{25}$ The British road protesters in the 1990s relied on resources from environmental organisations, highlighting the importance of enrolling allies and framing individual proposals as national issues. ${ }^{26}$ As other international studies have found, protestors often draw on a range of meaningful frames and demands to make road proposals visible as national issues. ${ }^{27}$ More recently, in Australia, there have been several contentious

23 Timothy Doyle and Doug McEachern, Environment and Politics (London: Routledge, 2007).

24 Raymond Mohl, 'Stop the Road: Freeway Revolts in American Cities,' Journal of Urban History 30, no. 5 (2004): 674-706.

25 Mimi Sheller and John Urry, 'The City and the Car,' International Journal of Urban and Regional Research 24, no. 4 (2000): 751.

26 Doherty, 'Paving the Way,' 283.

27 North, 'Save our Solsbury'; Boudet, 'From NIMBY'; Rootes, 'From local conflict.' 
road projects that have become trans-local and supra-local issues and have involved non-local actors. Legacy explains that opposition to an inner-city road tunnel in Melbourne involved campaigning in the outer suburbs of Melbourne and forming 'pro-public transport alternative movements' ${ }^{28}$ Similarly, the opposition against the contentious WestConnex motorway in Sydney involved local and non-local actors and alliance building with protest groups in Sydney. ${ }^{29}$

These anti-roads campaigns reveal that action on a wider scale is possible, but that there are significant challenges involved in connecting a local objection to broader supra-local or national issues. Consequently, I focus below on the political logics that underpin the strategies employed by opponents of the Kāpiti expressway. Various scholars have examined the political logics of campaigns against infrastructure projects in the European context by utilising discourse theory and Laclau's theoretical approach to populism. ${ }^{30}$ As a theoretical concept, populism provides a useful contrast between two ideal-types of political engagement that are commonly utilised by opponents of infrastructure proposals: an institutionalist mode of politics that finds faults in the planning process and a collective or populist form of action that links particular objections to a proposal to a wider challenge to a government's or project-sponsor's infrastructure programme. I use Laclau's theoretical insights to argue that institutionalist modes of political engagement can function as a roadblock to collective forms of political action.

\section{Analytical approach and research methods}

Laclau's notion of populism and concepts from Griggs and Howarth's

28 Legacy, 'Transforming Transport Planning,' 3118.

29 Haughton and McManus, 'Participation'; 'Identifying and Resisting the Financialization of the WestConnex Motorway, Sydney, Australia,' Environment and Planning A 53, no. 1 (2021): 131-149.

30 For example: Griggs and Howarth, 'Protest Movements'; 'Populism'; Tafon et al., 'The politics.' 
poststructuralist theoretical framework are useful for understanding the challenges of forming a sustained supra-local or national anti-expressway campaign. The basic unit of analysis in these theoretical approaches to populism is called a 'demand' and can be explained with a hypothetical example. If a citizen is concerned that their health would be affected by a proposed road near their home, they could make various singular or isolated demands to a relevant authority (for instance, a request to halt the proposal or a claim that focuses on a legal wrong) that responds to the demands individually and in a way that maintains the status quo. ${ }^{31}$ Griggs and Howarth call these isolated demands an institutionalist form of politics' because they are 'put forward in a piecemeal or punctual fashion, and addressed by power holders without altering the existing consensus'. ${ }^{32}$ However, when isolated demands are not satisfied, concerned citizens can sometimes look to other people who have demands that are not being satisfied (for instance, environmental demands) to find similarities or equivalences between their demands. ${ }^{33}$ If these people believe that there is a growing divide between them and the authority, then they may start to form a sense of collective agency based on a political frontier or antagonistic relationship between 'us' ('the people', 'underdog', 'community', and so on) and 'them' (the 'authority' or 'establishment'). ${ }^{34}$

Isolated demands start to become populist demands when they are attached to an empty signifier or a form of representation within a discourse that people with different interests and identities can relate to. ${ }^{35}$ In a populist mode of politics, an empty signifier is related to a collective subject ('the people') that has unsatisfied demands and/or the antagonistic relationship between the 'underdog' and the 'establishment'. ${ }^{36}$ For example, groups opposed to an infrastructure proposal often develop slogans (such as

31 Griggs and Howarth, 'Populism,' 128.

32 Griggs and Howarth, 'Populism,' 129.

33 Laclau, On Populist Reason, 73.

34 Griggs and Howarth, 'Protest Movements,' 315.

35 Griggs and Howarth, 'Populism,' 128.

36 Griggs and Howarth, 'Protest Movements,' 315. 
'we-don't-want-wind-farms') that bring together people who have different reasons for opposing the proposal. ${ }^{37}$ When isolated demands are connected to an empty signifier, equivalences between the demands are created by 'emptying' their individual meanings and creating 'a more universal identity that embodies a shared goal that is to be strived for' ${ }^{38}$

It is important to acknowledge that populism can lead to a type of politics that excludes or marginalises minority groups and their particular demands. Because particular demands can be subordinated to more universal demands, significant tensions can surface in populist modes of politics. For example, if a trade union joins forces with an anti-racist group by relating their demands for an immediate end to police harassment to the long-term goal of socialist revolution then there is a risk that shortterm struggles will be ignored in this wider quest. ${ }^{39}$ Laclau acknowledges that differences can be weakened in populist strategies, but he argues that chains of equivalence do not altogether eliminate differences because if the particularity of the demands disappears, there is no ground for the equivalence either'. ${ }^{40}$ In other words, there is a tension between particular and more universal demands, but particular demands are the foundation for the universal demand: if the foundation breaks or vanishes then the universal demand crumbles.

In this research, I conducted a qualitative analysis of media reports and other publicly available material on the Kāpiti expressway that were produced by opposition groups and from the planning and publicconsultation process. I also observed three protests and completed ten semi-structured interviews. The protests I attended were organised by anti-expressway and environmental groups in 2013. The semi-structured interviews were conducted with residents, members of anti-expressway groups, and a spokesperson from Generation Zero. The interviews

37 Tafon et al., 'The Politics,' 168.

38 Tafon et al., 'The Politics,' 168.

39 Jeremy Gilbert, Anticapitalism and Culture: Radical Theory and Popular Politics

(Oxford: Berg, 2008), 156.

40 Laclau, On Populist Reason, 79. 
explored how alliances were created and how the participants connected their particular interest in the proposal with wider environmental demands and other appeals to the common good. The interviews were also used to understand how opponents engaged with the highway proposal and their reasons for opposing it.

In what follows I specifically focus on the protest actions of Save Kāpiti, The Alliance for a Sustainable Kāpiti (ASK), and Generation Zero because they organised a sustained anti-expressway campaign. I focus on two protests that were organised by Save Kāpiti in February 2011, and Generation Zero's 100\% Possible campaign. I have selected these particular protests because they were the largest events that were organised in 2011 and 2013 . The $100 \%$ Possible campaign is examined because it was the only national protest that made the expressway part of a wider campaign that challenged the government's transport and energy policies.

\section{Expressway protests and populist politics}

In 2009, the NZTA consulted the public on three possible routes for the Kāpiti expressway by asking them what their 'preferred option' was- that is, asking them where the route for the new expressway should be built. ${ }^{41}$ The feedback from many local Kāpiti Coast residents suggested that they were opposed to these options and their preferred option was an upgrade of the existing highway combined with a new local road for residents. However, when the NZTA selected the expressway route, it emphasised that it was its board's preferred option. The selected expressway option was located on a corridor of land that deviates from the existing highway. This land was previously earmarked for the smaller local road that many residents supported. The NZTA acknowledged that its 'decision differs

41 The preferred option, as I have argued elsewhere, functioned as an empty signifier that was used by opponents to connect their individual concerns with the wider issue of the adequacy of public participation in issues that can negatively affect local communities: Hamlin, 'Antagonism.' 
from the preference of the many'. ${ }^{42}$

When the controversial route for the expressway was confirmed by the NZTA, local opposition groups engaged with a populist style of politics by claiming that residents were not adequately consulted or listened to. The anti-expressway groups created a political frontier between 'the people of Kāpiti' and the 'central government' by highlighting the unpopularity of the NZTA's preferred option. For example, an anti-expressway rally in 2011, which was organised by Save Kāpiti and ASK, objected to the NZTA's decision by presenting a petition to the minister of transport and the prime minister. ${ }^{43}$ The web-based version of the petition claimed that 'the decision process has been divisive, manipulative, and lacking information. Instead of consulting the community about possible solutions to the problems, we were only offered a choice between three equally unacceptable expressway routes' ${ }^{44}$ Moreover, the rally and press releases associated with the petition mobilised populist appeals that created a political frontier between the 'Kāpiti Coasters', who are 'fight[ing] to protect their seaside community', and the government that is 'bullying' and 'not listening' to the community. ${ }^{45}$

The use of a petition to highlight the unpopularity of the NZTA's preferred option emphasise what Griggs and Howarth call 'the degree of division and contestation brought about by a political mobilization or practice'. ${ }^{46}$ For instance, a spokesperson for Save Kāpiti claimed that 'the 4,000 signatures represent three times the number who chose the expressway to go on the Western Link route during the poorly handled 2009 NZTA consultation'. ${ }^{47}$ This quote illustrates how a large number of requests were brought together under the demand for majority rule in the

42 New Zealand Transport Agency, “"Milestone” decision: A 4-lane expressway from Levin to Wellington airport,' Scoop, 15 December 2009.

43 Hamlin, 'Antagonism.'

44 Alliance for Sustainable Kāpiti, 'Support the Kapiti Coast,' Care2 Petitions, http://www.thepetitionsite.com/1/kapiti-coast/

45 Bianca Begovich, 'Angry Kapiti Coast residents at parliament tomorrow,' Scoop, 5 July 2011.

46 Griggs and Howarth, 'Populism,' 129.

47 Save Kāpiti, “4000+ people hate the "Highway from Hell,”' Scoop, 30 June 2011. 
public-consultation process, which was signified by the 'preferred option'.

The anti-expressway petition and rally was underpinned by a populist logic, but it was a limited form of populism in the sense that it focused on halting the Kāpiti expressway proposal without broadening its demands to other struggles. While ASK and Save Kāpiti mobilised support to oppose the Kāpiti expressway, they did not connect their demands with broader opposition to automobility or road building. Instead, these groups focused on sustainable transportation in Kāpiti and addressing local traffic problems.

While populist campaigns can be local, national, or global, a narrow focus can weaken the ability to forge alliances with other groups and demands. Rather than highlighting similarities with other protest groups, staying at the local level can reveal points of difference and conflict with environmental organisations that oppose all expressway proposals. ${ }^{48}$ From my interviews, I found that anti-expressway groups decided to focus on the single issue of opposing the Kāpiti expressway because they believed that an evidence-based approach would help them appear politically neutral and would expose what they believed were fundamental weaknesses with the proposal. For example, they focused on the issues of traffic decline on the Kàpiti Coast, the low cost-benefit ratio of the proposal, and the proposal's impact on ecologically sensitive areas in Kāpiti, to name just a few. In 2011, the proposal was still in its design and planning phases so focusing on the specific problems with the proposal appeared to be an appropriate strategy: it was thought that it would help spark interest in the proposal and encourage local residents to make a submission to the Board of Inquiry in 2012.

The anti-expressway rally was also a restricted form of populist engagement in the sense that it tried to influence the planning process with the use of rational arguments that could be responded to on an individual basis by relevant authorities or politicians. This strategy tended to weaken the formation of a populist campaign because the demands that are made within the planning process can be responded to on an individual basis by relevant authorities. The rally and associated press releases revealed that the 
anti-expressway groups and protestors were interested in challenging the proposal from within existing institutional arrangements. The press releases and publicly available photos of the protest reveal that protesters mobilised a mix of institutionalist appeals that urged the National-led government to change its decision and broader appeals to environmental protection and public participation. In one sense, the protest followed an institutionalist form of politics by targeting politicians and asking them to reconsider their decision to build an expressway through Kāpiti. For instance, a press release by Save Kāpiti challenged the NZTA's economic analysis by claiming that the proposal would not 'deliver the economic growth the government claims' and that alternative transport options would solve Kāpiti's traffic problems, but without the ' $\$ 550$ million price tag'. ${ }^{49}$ The use of economic and transport planning arguments indicated that opponents believed that engaging with the planning aspects of the proposal was an appropriate strategy that would help challenge it while also gaining support from other citizens who were interested in finding faults with the NZTA's proposal.

To clarify, while the anti-expressway rally was a restricted form of populism that utilised a mix of institutional and populist appeals, it was not a distinct, single-issue campaign that was only relevant to the local residents on the Kāpiti Coast. As I will discuss below, the anti-expressway protests in 2011 helped attract the attention of environmental groups that were using the expressway proposals to engage with the wider issues of sustainable transportation and climate change. The references to wider environmental issues in their protests brought into focus the overlapping interests between local opposition groups and national environmental organisations and the potential for future alliances, revealing how seemingly isolated demands from local groups can be extended to a different sphere by using them as symbols for wider environmental problems. ${ }^{50}$

49 Save Kāpiti, ‘4000+ people hate.’

50 Howarth and Griggs, 'Metaphor, Catachresis and Equivalence: The Rhetoric of Freedom to Fly in the Struggle Over Aviation Policy in the United Kingdom,' Policy and Society 25, no. 2 (2006): 23-46. 


\section{Alliances with environmental organisations}

While the shared interests between local groups and environmental organisations were made visible by the anti-expressway protestors, the creation of an alliance and populist political campaign was not an automatic process. In 2012, one year after the anti-expressway rally, the climate-change group Generation Zero became publicly involved in the Kàpiti expressway proposal when it used it to critique the government's lack of commitment to climate change and imperceptible progress towards a carbon-free future. Like the anti-expressway groups, Generation Zero was concerned with the economic and planning justifications of the Kāpiti expressway. Initially, it engaged in an institutionalist form of politics by making a submission to the Board of Inquiry. A spokesperson for Generation Zero stated that there 'doesn't seem to be a lot of justification for a project this size ... [and] it isn't delivering a lot of [the proposed] benefits'. He said that Generation Zero was following the progress of the RoNS proposals more generally in order to advocate for a 'rebalancing of the transport budget', but when it became aware of the Kāpiti expressway proposal, the group thought that 'it really stood out as a project we think doesn't stack up on any count'. Generation Zero's submission to the Board of Inquiry focused on the popular issue of climate change, but the group connected it to the particular issues of traffic forecasting and how the NZTA justified the benefits of the proposal. The group's spokesperson explained that 'the RMA [Resource Management Act] requires the effects of climate change to be considered' in the planning process, but the NZTA did not mention how climate change would affect the economic aspects of the proposal.

Generation Zero's submission to the Board of Inquiry was an institutionalist form of politics in the sense that its arguments were processed by a political authority. At this stage, the group had not engaged in a more populist style of political engagement that attempted to challenge the hegemony of automobility and expressway-building in Aotearoa New Zealand. Generation Zero and other environmental groups had not launched a supra-local or national protest campaign that attempted to 
win popular support and challenged the ideological context that made the expressway proposals appear acceptable as a course of action. ${ }^{51}$ As discussed above, Generation Zero initially pursued an institutionalist strategy because the proposal seemed to be riddled with problems. It was thought that exposing the weaknesses with the proposal would help stop it and would also bring attention to the issue of climate change.

Generation Zero's institutionalist strategy highlights how antiexpressway groups and environmentalists can oppose a common issue while pursuing their separate interests. Submitting evidence through the planning process does not link demands or create alliances between diverse groups, but it can, in this case, be an effective political strategy that advances the interests of both groups. For the local opposition groups, having environmental groups making submissions to the Board of Inquiry could help halt the proposal by revealing its negative environmental impacts. For Generation Zero, the submissions made by local groups could help the group stop Aotearoa New Zealand's dependence on fossil fuels and could help raise awareness of the environmental problems associated with automobility. The submissions made by these two groups indicate that populism is not an ideal political logic that should always be pursued. Rather, the decision to pursue a particular strategy is dependent on a range of different considerations, resources, and variables. ${ }^{52}$

While an institutional strategy appeared to be an appropriate choice in the lead-up to the inquiry, Generation Zero changed strategy once the board released its decision to approve the proposal. It shifted to a more populist form of protest that connected the expressway to the $100 \%$ Possible climate-change campaign, which was organised along with the climate-change organisation 350 Aotearoa. Rather than challenging the board's decision legally, Generation Zero linked the decision to build it to the wider struggle to shift Aotearoa New Zealand beyond fossil fuels and the demands from other environmental groups, such as 350 Aotearoa and the World Wide Fund for Nature. This decision to join forces with other

51 Griggs and Howarth, 'Populism.'

52 Griggs and Howarth, 'Populism.' 
environmental organisations re-articulated the local demand for a smaller two-lane road with a request for the government to invest in infrastructure that would reduce Aotearoa New Zealand's reliance on fossil fuels. A series of protests in Wellington, Auckland, and Dunedin focused on the Kāpiti expressway proposal as an example of 'wasteful spending' on road proposals that were based on outdated, 'dinosaur' thinking and 'prehistoric' policy. The 'Prehistoric Policy', dinosaur-themed protest in Wellington argued that the $\$ 630$ million dollars required to build the expressway should be used for a more cost-effective road and investments in cycleways and light rail. This request helped strengthen the anti-expressway group's demand for a smaller two-lane road, which was more cost effective, while making a broader proposal for greater investment in more environmentally friendly cycling and rail infrastructure.

Further, as the Prehistoric Policy protest was staged in three major cities, it helped publicise the Kāpiti expressway as a national, rather than a local, issue. While the protest emphasised the importance of stopping the Kāpiti expressway in particular, its focus was on the wider, national issue of investing in 'smart', low-carbon transport projects to address climate change. A national protest that focused on the wider issue of low-carbon transport helped create possibilities for developing alliances with other activist groups that were concerned with the environment, infrastructure, transport, and the management of resources.

The 100\% Possible campaign helped link the expressway proposal with wider environmental issues, but the weak alliances between Generation Zero and local opposition groups meant that a populist political campaign that created an antagonism between the government and New Zealand citizens did not materialise: it did not highlight the fact that local residents had been treated badly by the government. Here, the absence of populist appeals from local residents potentially weakened the links between the protest groups and the possibility of creating a populist campaign that forged alliances with environmental organisations and locally based groups. 


\section{Expressway protests and institutionalist politics}

The possibility of creating a populist anti-expressway campaign seemed to dwindle when the protests organised by anti-expressway groups in 2013 focused on the legal/institutional issue of acquiring properties while the expressway proposal was before the High Court. Like their previous demonstrations, the protestors referenced the wider undemocratic and environmental issues with the proposal. However, the purpose of the protest was to stage a sit-in at a garden centre in Raumati South that was supposedly being forcefully acquired by the government. By organising the event at a well-known garden centre and home that was supposedly being forcefully acquired by the government, Save Kāpiti and the owner of the property were able to demonstrate to news reporters and passers-by that the NZTA's actions were legally questionable.

While the garden-centre protest appeared to be an institutionalist form of political engagement, its reference to the antagonistic relations between the government and local residents suggests that the opponents continued to enact a restricted form of populist politics. The protestors' placards highlighted the divide between the government and New Zealand citizens by claiming the government 'does not care' and that Kāpiti was being sacrificed because of the government's politically motivated road-building agenda. The plight of the garden-centre owner brought into focus the issue of antagonism by highlighting the disadvantage, intimidation, and sense of injustice experienced by affected residents.

However, Save Kāpiti’s garden centre protest did not seek to publicly strengthen its alliances with national environmental groups. By focusing on the local impact on property owners and the character of the beachside communities, Save Kāpiti indicated that it was not expanding beyond the single issue of opposing the Kāpiti expressway or forming a wider campaign that united anti-expressway and environmental groups. Rather than widening its demands after an unsuccessful attempt at persuading the Board of Inquiry to decline the proposal, the group continued to focus on appeals to reason and legal arguments. 
Ultimately, opponents of the expressway proposal engaged in a restricted form of populist politics that mixed institutionalist and populist logics. The decision to highlight the wider issues of public participation and environmentalism indicated that a populist logic could have been developed and enacted in their anti-expressway campaign. However, their reliance on an institutionalist logic of finding faults in the planning process meant that the difficult task of forming alliances and constructing equivalences was not their main focus.

\section{Conclusion}

Institutionalist modes of political engagement are one way that concerned citizens can oppose controversial transportation proposals, among other issues. If locally based groups can mobilise experts to launch a legal appeal, then this individualistic form of politics can directly challenge controversial infrastructure proposals. While the Kāpiti expressway protests made the proposal publicly visible as an environmental and social issue, it only surfaced for a brief moment as a national issue. But institutionalist forms of political engagement can restrict the possibilities for collective action and the formation of supra-local or national campaigns by channelling political energy into fault-finding exercises. By engaging in legal appeals and other institutionalist modes of engagement, opponents are confronted with organisations that have significant resources and networks, often putting them into a 'reactive position with little time to mobilise a proper fight'. ${ }^{53}$

While an institutionalist response to the planning process is understandable, it is often part of a broader post-political planning process in which proposals are depoliticised, making collective action and politicisation challenging. ${ }^{54}$ Moreover, institutionalist responses can feed into the idea that proposals are nonissues because this form of opposition does not transcend a 'NIMBY framing' of local residents attempting to

53 Legacy, 'Transforming Transport Planning,' 3117.

54 Haughton and McManus, 'Participation,' 321. 
preserve their 'existing liveability'. ${ }^{5}$

The individualistic and collective modes of engagement with the Kāpiti expressway proposal thus reveal the challenges of forming anti-expressway campaigns that go beyond local opposition. For opposition groups, one possible challenge of pursuing a populist campaign with environmental groups and other organisations was that its primary goal of stopping the Kāpiti expressway proposal would be subordinated to the wider struggles for sustainable transport and climate-change action. Here, the Kāpiti expressway proposal would have become a mere symbol of what is wrong with the government's policies rather than an issue that needs to be actively opposed in court or through other means. However, even if supra-local campaigns do not stop particular proposals from proceeding, they can be 'successful' in the sense that they may be connected with other campaigns, which might eventually stop other controversial proposals from proceeding or might positively influence transport policy or planning in terms of, for example, advocating for alternative proposals or challenging dominant automobility discourses.

On the other hand, from the perspective of an environmental organisation, an alliance with opposition groups could detract from the goal of influencing government policy if it becomes too involved in the campaigns to stop particular road proposals. For instance, if Generation Zero and the local groups successfully opposed the Kāpiti expressway and helped resurrect the smaller two-lane road proposal, would this outcome be a victory for the environmental movement and their climate-change campaign? A two-lane road proposal would still have a significant environmental impact and it would not significantly challenge the hegemony of automobility in Aotearoa New Zealand. In their study of airport expansion in the UK, Griggs and Howarth reached a similar conclusion, suggesting that a victory for a local opposition group does not automatically translate into the building of 'broader political projects necessary to advance demands for more environmentally friendly public policies. ${ }^{56}$

Populist modes of political engagement reveal how anti-expressway

55 Legacy, 'Transforming Transport Planning,' 3118.

56 Griggs and Howarth, 'Populism,' 140. 
groups can pursue their particular goals while also linking their diverse demands to a wider challenge to a government's controversial national transport policies and environmental issues. It is understandable that institutionalist strategies for opposing an issue can be a logical choice. Finding faults in the planning process, identifying a legal wrong, or other legitimate issues can provide an avenue for addressing a group's concerns and pursuing their interests. However, when this form of action is unsuccessful, or when funds for legal costs are exhausted, the limitations of institutionalist politics are revealed. If this occurs, as it did for Save Kāpiti and ASK, then an investment in an institutionalist strategy can mean that connections with potential allies are not developed and, therefore, potential avenues for collective action can be diminished. Indeed, it is a well-known tactic of proponents of infrastructure proposals to label opponents as NIMBYs. Therefore, an institutionalist focus that does not seek support from non-local actors or an articulation with supra-local issues can feed into NIMBY framings and work against effective collective opposition. ${ }^{57}$

In Aotearoa New Zealand, progressive forms of populist and collective action that politicise issues are important because diverse groups and individuals are affected by public issues that pose a risk to human health and have significant environmental implications. ${ }^{58}$ The emphasis on individual interests and institutional/isolated forms of action, which are often part of a post-political planning process, means that developing strategies to link demands for collective action is an important problem encountered by local groups and activists who seek to effectively oppose or stop problematic proposals from proceeding. It is critical that citizens not only engage with established political institutions, but also join forces for effective collective action that politicises seemingly local or NIMBY problems as broader public issues that are contestable.

57 Rootes, 'From Local Conflict.'

58 MacArthur and Matthewman, 'Populist Resistance'; Hird et al., 'Making Waste Management'. 